\title{
Investigating the Induced Systemic Resistance Mechanism of 2,4-Diacetylphloroglucinol (DAPG) using DAPG Hydrolase-Transgenic Arabidopsis
}

\author{
Dae-Han Chae', Da-Ran Kim², Mi Sun Cheong', Yong Bok Lee ${ }^{1}$, and Youn-Sig Kwak (iD) 1,2* \\ ${ }^{1}$ Division of Applied Life Science (BK21Plus) and Institute of Agriculture \& Life Science, Gyeongsang National \\ University, Jinju 52828, Korea \\ ${ }^{2}$ Department of Plant Medicine, Gyeongsang National University, Jinju 52828, Korea
}

(Received on November 14, 2019; Revised on February 9, 2020; Accepted on March 6, 2020)

Plant immune responses can be triggered by chemicals, microbes, pathogens, insects, or abiotic stresses. In particular, induced systemic resistance (ISR) refers to the activation of the immune system due to a plant's interaction with beneficial microorganisms. The phenolic compound, 2,4-diacetylphloroglucinol (DAPG), which is produced by beneficial Pseudomonas spp., acts as an ISR elicitor, yet DAPG's mechanism in ISR remains unclear. In this study, transgenic Arabidopsis thaliana plants overexpressing the $D A P G$ hydrolase gene (phlG) were generated to investigate the functioning of DAPG in ISR. DAPG was applied onto 3-week-old $A$. thaliana Col-0 and these primed plants showed resistance to the pathogens Botrytis cinerea and Pseudomonas syringae pv. tomato DC3000. However, in the phlG transgenic $A$. thaliana, the ISR was not triggered against these pathogens. The DAPG-mediated ISR phenotype was impaired in transgenic $A$. thaliana plants overexpressing $p h l G$, thus showing similar disease severity when compared to untreated control plants. Furthermore, the DAPG-treated $A$. thaliana Col-0 showed an increase in their gene expression levels of PDF1.2 and WRKY70

\footnotetext{
*Corresponding author.

Phone) +82-55-751-3259, FAX) +82-55-751-3257

E-mail)kwak@gnu.ac.kr

ORCID

Youn-Sig Kwak

https://orcid.org/0000-0003-2139-1808

(c) This is an Open Access article distributed under the terms of the Creative Commons Attribution Non-Commercial License (http:// creativecommons.org/licenses/by-nc/4.0) which permits unrestricted noncommercial use, distribution, and reproduction in any medium, provided the original work is properly cited.
}

Articles can be freely viewed online at www.ppjonline.org. but this failed to occur in the phlG transgenic lines. Collectively, these experimental results indicate that jasmonic acid/ethylene signal-based defense system is effectively disabled in $p h l G$ transgenic $A$. thaliana lines.

Keywords : 2,4-diacetylphloroglucinol (DAPG), antimicrobial, induced systemic resistance (ISR), phlG, Pseudomonas

Handling Editor : Kee Hoon Sohn

Plant immunity is activated by several triggers, which may consist of not only biotic factors, such as beneficial microbes, arthropods, and pathogens (Boller and Felix, 2009; Engelberth et al., 2004; Koo et al., 2020; Pieterse et al., 2014; Yoo and Sang, 2017), but also abiotic stresses including chemical inducers and salinity (Beckers and Conrath, 2007). The local immune system can recognize these key stimuli and respond by inducing local and systemic immune responses. Certain substances, namely salicylate, azelaic acid, and jasmonate, are used for this systemic induction of plant immunity (Dempsey and Klessig, 2012).

The bacterium Pseudomonas fluorescens Q2-87, a wellknown biocontrol agent, produces 2,4-diacetylphloroglucinol (DAPG) (Raaijmakers and Weller, 2001). DAPG is a phenolic compound exhibiting a wide spectrum of antibiotic activity against bacteria, fungi, and nematodes (Haas and Keel, 2003; Weller et al., 2007). Genetic analyses using different DAPG-producing or -nonproducing $P$. fluorescens strains have revealed that DAPG is indeed a key antibiotic agent which is effective against different soilborne pathogens (Keel et al., 1992). In the host plant, DAPG may either directly inhibit soil-borne pathogens or 
indirectly do so by activating induced systemic resistance (ISR) (Kwak and Weller, 2013). ISR is phenotypically and biochemically related to systemic acquired resistance (SAR) in plants, which is usually induced via infection with avirulent pathogens. SAR is mediated by the salicylic acid (SA)signaling pathway in plants acquiring systemic resistance and is regulated by the redox-regulated protein NONEXPRESSER OF PR GNENS 1 (NPR1) (Cao et al., 1997). It was recently shown that SAR contributes to the expression of PATHOGENESIS-RELATED (PR-1), PR-2, and $P R-5$, which are SA signal-responsive genes (Nie et al., 2017). By way of comparison, ISR is mediated by jasmonic acid (JA)/ethylene (ET)-signaling pathways, and NPR1 also plays important roles in how this defensive response is executed by plants (Pieterse et al., 1998). It is known that ISR can switch on JA- and ET-responsive genes' expression, namely of ChiB and PDF1.2, LOX1, LOX2, PAL1, and PIN2, as well as VSP (van Wees et al., 1999).

DAPG-induced ISR has been shown to confer plant resistance to a variety of plant pathogens. In Arabidopsis, root-colonizing $P$. fluorescens $\mathrm{CHA} 0$ prevented sporulation of the oomycete Peronospora parasitica, whereas DAPGdeficient strains, such as CHA 89 (HCN, DAPG-, and pyoluteorin-deficient) and CHA631 (DAPG-deficient strain) did not protect the plant from the pathogen's attack (Iavicoli et al., 2003). Importantly, the P. fluorescens- or DAPGmediated ISR responses did not occur in the Arabidopsis mutants npr1-1 (non-expressing NPR1 protein), jarl-1 (JA-insensitive), and eirl-1 (ET-insensitive) (Iavicoli et al., 2003). Similarly, ISR mediated by DAPG was critical for enacting plant resistance via the JA/ET-signaling pathway against Pseudomonas syringae (Weller et al., 2012). The DAPG-producing P. fluorescens strain Q287 was capable of induced resistance against the pathogen $P$. syringae pv. tomato, which causes bacterial speck disease, and this protection occurred in transgenic Arabidopsis plants carrying the SA degrading gene $(\mathrm{NahG})$ but not in Arabidopsis mutants nprl-1, jarl, and etr 1 (Weller et al., 2012). Collectively, these findings indicate that DAPG-mediated ISR relies on the JA/ET-signaling pathway.

Nevertheless, using mutants that lack a specific hormonal signaling pathway can produce misleading results and a crucial misunderstanding of the role of specific hormones in the evolutionary development of disease resistance (Seif El-Yazal et al., 2015). Ethylene and auxin, for example, can govern a number of common processes in plants, including their primary root elongation, root hair formation, hook formation, epinasty of leaves, and leaf abscission (Stepanova et al., 2005). Additionally, the hormones under- pinning ISR figure prominently in shaping the resistance of plants to pathogens. SA is involved in plants' resistance to biotrophic pathogens, whereas JA/ET is involved in their resistance to necrotrophic pathogens/insects, respectively (Lievens et al., 2017). Therefore, studying the ISR system with only single gene knockout Arabidopsis mutant may provide only partial or indirect evidence for the mechanisms of plant defense.

In this study, DAPG-tolerance Arabidopsis lines were developed by transforming the activity of DAPG hydrolase, via the $p h l G$ gene. The $p h l G$ encodes an enzyme that catalyzes the functioning of acetyltransferase to convert antibiotic DAPG to its non-toxic monoacetylphloroglucinol (MAPG) form (Bottiglieri and Keel, 2006). This work further dissects the role and function of DAPG in ISR by using a transgenic plant that degrades DAPG.

\section{Materials and Methods}

Plant, bacterial and fungal materials. Arabidopsis thaliana Col-0 was used as the experimental model plant. The plants were cultivated in bed soil or media. Seed was sown in the bed soil (a mixture of cocopeat, peat moss, zeolite, and vermiculite), and each pot held three or four seeds. After 7 days of cultivation, when the plant had grown large enough to be identified, one plant was transferred into another pot to grow. For plant growth on media, seed sterilization was first performed with $1 \% \mathrm{NaOCl}$. Vernalization was achieved with $1 \mathrm{ml}$ of distilled water, at $4^{\circ} \mathrm{C}$, for 7 days under a dark condition. Murashige and Skoog (MS) agar media (2.1 $\mathrm{g}$ of MS salt, $30 \mathrm{~g}$ of sucrose, $0.7 \mathrm{~g}$ per 1 liter of phytoagar) was adjusted to $\mathrm{pH}$ 5.7-5.8 with $1 \mathrm{M}$ of $\mathrm{KOH}$ and autoclaving. Arabidopsis was grown in a growth chamber (Seyoung Scientific, Bucheon, Korea) under the following conditions: $12-\mathrm{h} / 12$-h, light/dark cycle, $22^{\circ} \mathrm{C}$, $60 \%$ relative humidity and 1,390 lux (light intensity).

The bacterium Pseudomonas fluorescens Q2-87 was incubated on $1 / 5$ TSA (tryptic soy broth $[6 \mathrm{~g} / 1]$ with agar $[20 \mathrm{~g} / 1]$ ) at $27^{\circ} \mathrm{C}$ for 2 days. The challenging pathogen Pseudomonas syringae pv. tomato DC3000 (Pst DC3000) was incubated on $1 / 5 \mathrm{TSA}$ at $27^{\circ} \mathrm{C}$ for 2 days. A single colony was cultured in $5 \mathrm{ml}$ of TSB liquid medium (tryptic soy broth, $30 \mathrm{~g} / \mathrm{l}$ ) at $27^{\circ} \mathrm{C}$ for $48 \mathrm{~h}$, and then inoculated into $200 \mathrm{ml}$ of TSB. The cultured cells were collected by centrifugation and re-suspended in $10-\mathrm{mM} \mathrm{MgCl}_{2}$, then $0.01 \%$ (v/v) of the Silwet L-77 (PhytotechLABS, Shawnee Mission, KS, USA) was added and cell density adjusted to $1 \times 10^{7}$ colony-forming unit $(\mathrm{cfu}) / \mathrm{ml}$.

The fungal pathogen Botrytis cinerea was cultivated on PDA (potato dextrose broth [24 g/l] with agar [20 g/l]) at 
$27^{\circ} \mathrm{C}$ for 7 days. Its mycelium and spores were collected in sterilized water with a cotton swab, which was filtered through three layers of sterilized cheesecloth to collect the individual spores. The spore concentration was adjusted to $1 \times 10^{5} \mathrm{cfu} / \mathrm{ml}$ by using a hemocytometer (SUPERIOR, Lauda, Germany).

DAPG sensitivity test of $A$. thaliana Col-0. HPLC-grade methanol was used as a solvent for DAPG (Santa Cruz Biotechnology, Dallas, TX, USA), which had a stock concentration of $100 \mathrm{mM}$. This stock was stored at $-20^{\circ} \mathrm{C}$ under dark conditions. DAPG stock was added to MS media to obtain final concentrations of 20, 40,60,80, and $100 \mu \mathrm{M}$, and each respectively poured into a $(90 \mathrm{~mm} \times$ $15 \mathrm{~mm}$ ) petri dish and dried on a clean bench. The vernalized seeds were sown at a density of 100-200 seeds per dish and cultivated in the growth chamber for 10 days. This experiment was conducted using three replications. Statistical analysis was performed by Tukey's honestly significant difference (HSD) test $(P<0.05)$.

Detection and purification of $p h l G$ gene. The $p h l G$ cloning primers (Supplementary Table 1) were designed with $P$. fluorescens Q2-87 reference sequences currently registered in NCBI [Locus_tag: PflQ2_2239]. The primers were synthesized by Cosmo Genetech (Seoul, Korea). The PCR mixture was $50 \mu \mathrm{l}$, comprising $2 \mathrm{mM}$ of dNTPs, $2 \times$ PCR Buffer of KOD FX Neo, $1 \mu \mathrm{g}$ of template DNA, $1.0 \mathrm{U}$ KOD FX Neo, and $0.2 \mu \mathrm{M}$ of each primer. The PCR reaction was performed as touchdown PCR, whose cycling began with a denaturation and annealing temperature of $83^{\circ} \mathrm{C}$ for 5 cycles, then reducing the annealing temperature $1^{\circ} \mathrm{C}$ every 5 cycles to $73^{\circ} \mathrm{C}$, followed by 10 more cycles run at $73^{\circ} \mathrm{C}$. Each primer was designed to amplify an $882-$ bp product, and the PCR product identified by gel electrophoresis in $1 \%$ agarose. Gel purification was done using Expin Gel SV (GeneAll, Seoul, Korea). To ligate with a donor vector, the purified PCR product underwent an Atailing reaction $(20 \mu \mathrm{l})$ as follows; dATP (NEB, Ipswich, MA, USA), 10 $\times$ Reaction Buffer, and 5 units of TOP DNA Polymerase (Bioneer, Daejeon, Korea); the mixture was treated at $70^{\circ} \mathrm{C}$ for $30 \mathrm{~min}$. DNA quantification was measured on a NanoDrop 2000C (Thermo Fisher Scientific, Waltham, MA, USA) to confirm its concentration and quality, after which it was stored at $-20^{\circ} \mathrm{C}$.

Binary vector construction. The PCR8/GW/TOPO (Invitrogen, Waltham, MA, USA) plasmid served as the entry vector. The reaction mixture $(2 \mu \mathrm{l}$ of the A-tailed PCR product, $0.5 \mu \mathrm{l}$ of salt solution, and $0.5 \mu \mathrm{l}$ of the PCR8/
$\mathrm{GW} / \mathrm{TOPO}$ vector) was incubated at room temperature for $5 \mathrm{~min}$. The plasmid was transformed into Escherichia coli DH5 $\alpha$ using the heat shock protocol. The selection of transformed donor vector $E$. coli was performed in LuriaBertani (LB) media containing the antibiotic spectinomycin $(50 \mu \mathrm{g} / \mathrm{ml})$. For plasmid isolation, using a single colony inoculation, cells were cultured in $5 \mathrm{ml}$ of LB broth at $37^{\circ} \mathrm{C}$ for $16 \mathrm{~h}$ in a shaking incubator. The plasmid was extracted with the DokDo-Prep plasmid mini-prep kit (ELPIS Biotech, Daejeon, Korea). The gateway destination vector (pMDC43) containing a hygromycin resistance gene ( $h p t)$ was used for transgenic Arabidopsis selection; pMDC43 was introduced into transformed E. coli DB3.1. The selection was performed on LB media containing kanamycin (50 $\mu \mathrm{g} / \mathrm{ml})$. The expression clone was constructed through the LR reaction of the entry clone and destination vector. This reaction solution contained $1.5 \mu$ of the destination vector mixed with $0.5 \mu \mathrm{l}$ of PCR8 clone and $0.5 \mu \mathrm{l}$ of LR Clonase (Invitrogen), and it was incubated at room temperature for 24 h. E. coli transformation and plasmid isolation proceeded as described above. The restriction enzymes EcoRI and $E c o$ RV (NEB) were used to confirm the correct insert in the entry clone and the expression clone. The reaction volume $(20 \mu \mathrm{l})$ comprised $2 \mu \mathrm{l}$ of EcoRI, $2 \mu \mathrm{l}$ of NEBuffer 2.1, $1 \mu \mathrm{g}$ of the plasmid, and distilled water. After incubation at $37^{\circ} \mathrm{C}$ for $3 \mathrm{~h}$, gel electrophoresis was used to examine the product's size whose DNA sequencing was then done by Cosmo Genetech.

Agrobacterium tumefaciens-mediated transformation. Agrobacterium tumefaciens GV3101 was used for plant transformation, via the electroporation methods. The binary vector was added into $100 \mu \mathrm{l}$ of GV3101 competent cells, and this mixture homogenized by gently stirring it with a pipette several times. The mixture was placed in a pre-chilled cuvette in which electroporation proceeded at a voltage (v) $2.5 \mathrm{kV} / \mathrm{cm}$. The cuvette was removed and $1 \mathrm{ml}$ of LB broth was immediately added; the solution was then transferred into a new Eppendorf-tube and incubated for $2 \mathrm{~h}$ in a $30^{\circ} \mathrm{C}$-incubator. The cells were selected in LB media containing gentamycin $(10 \mu \mathrm{g} / \mathrm{ml})$, rifampicin $(100$ $\mu \mathrm{g} / \mathrm{ml})$, and kanamycin $(50 \mu \mathrm{g} / \mathrm{ml})$. The floral-dip method was used for the Arabidopsis transformation (Clough and Bent, 1998). The GV3101 cells were cultured in $500 \mathrm{ml}$ of LB broth for $12 \mathrm{~h}$ and then harvested by centrifugation (4,000 rpm) for $20 \mathrm{~min}$. The harvested cells were suspended using an infiltration buffer ( $5 \%$ sucrose, $0.01 \%$ Silwet), after which Arabidopsis flowers were dipped in Agrobacterium mixture for $5 \mathrm{~min}$. Transformed plants were incubated for 2 days, at room temperature, under cover of the plastic 
pot, and grown in the chamber.

Selection of the phlG transgenic homozygous line $\left(\mathrm{T}_{3}\right)$. Arabidopsis $\mathrm{T}_{1}$ selection was performed in media containing DAPG and hygromycin. Arabidopsis was screened using a concentration of $80 / 100 \mu \mathrm{M}$ of DAPG that completely inhibited germination of the wild type (Col-0) (Supplementary Fig. 1); hygromycin was used in a final concentration of $57 \mu \mathrm{M}$. On each plate 100-150 seeds were sown in MS agar medium. After their 15-day cultivation in a growth chamber, resistant plants were transferred to bed soil. Each selected $\mathrm{T}_{1}$ plant was grown in the chamber for 2 months and harvested to obtain $\mathrm{T}_{2}$ generation seeds. From these, seedlings were sown on MS agar medium containing hygromycin $(57 \mu \mathrm{M})$ or DAPG $(100 \mu \mathrm{M})$. Segregation analysis was performed for the selection of the homozygous line. For this, 100-200 seeds were sown per plate and cultivated in the growth chamber for 7 days. Resistant and non-resistant populations were counted, for which a segregation analysis was based on significant differences assessed by the chi-square test in SAS software (v9.4, SAS Institute Inc., Cary, NC, USA).

Phenotype observations. Phenotypes of $A$. thaliana Col0 and $p h l G$ transgenic lines (D16, H2) were observed. MS medium (1.2\% agar) was used for their initial growth on plates grown vertically for 15 days in a growth chamber, after which the root length and weight of each plant were measured. The former was obtained from photographs analyzed using the ImageJ program (64-bit java v1.8.0_112). Fresh weight and leaf area were determined from 3-weekold plants in bed soil. The area per leaf was measured in ImageJ software. The data were statistically analyzed by Tukey's HSD test $(P<0.05)$, based on five biological replications.

Plant DNA extraction and inserted phlG identification. Genomic DNA from plant tissue was obtained using the Edward extraction protocol (Edwards et al., 1991). To identify the $p h l G$ transgenic line $\left(\mathrm{T}_{3}\right)$ PCR was used according to the gDNA and cDNA conditions. PCR volume $(50 \mu \mathrm{l})$ consisted of $2 \mathrm{mM}$ of dNTPs, $2 \times$ the PCR buffer for KOD FX Neo, $1 \mu \mathrm{g}$ of template DNA, KOD FX Neo $(1.0 \mathrm{U} / \mu \mathrm{l})$ and $0.2 \mu \mathrm{M}$ of each primer (same as before). PCR cycling using gDNA started with a denaturation and annealing temperature of $83^{\circ} \mathrm{C}$ for 5 cycles, then the annealing temperature was reduced by $1^{\circ} \mathrm{C}$ every 5 cycles to $73^{\circ} \mathrm{C}$ (same as above). The PCR conditions using the cDNA sample was carried out at $95^{\circ} \mathrm{C}$ for $30 \mathrm{~s}, 30$ cycles of the denaturation at $95^{\circ} \mathrm{C}$ for $30 \mathrm{~s}$, annealing at $56^{\circ} \mathrm{C}$ for $30 \mathrm{~s}$, followed by an extension at $72^{\circ} \mathrm{C}$ for $30 \mathrm{~s}$, with the final extension done at $72^{\circ} \mathrm{C}$ for $10 \mathrm{~min}$.

Plant RNA extraction and qRT-PCR. The $A$. thaliana Col-0 and phlG transgenic lines (D16, H2) were grown on MS medium for 10 days, snap frozen with liquid nitrogen and homogenized using a mortar and pestle. Their total RNA was extracted with the TRIzol reagent (Thermo Fisher Scientific), following the manufacturer's protocol. After quantification, cDNA was synthesized with $2 \mu \mathrm{g}$ of total RNA by using ReverTra Ace- $\alpha-\circledast$ (Toyobo, Osaka, Japan). Reaction volumes $(20 \mu \mathrm{l})$ were obtained by adding $4 \mu \mathrm{l}$ of $5 \times$ RT buffer, $2 \mu \mathrm{l}$ of dNTP Mixture $(10 \mathrm{mM}$ each), $1 \mu \mathrm{l}$ of RNase inhibitor (10 U/ $\mu \mathrm{l}), 1 \mu \mathrm{l}$ of Oligo (dT) $20(10 \mathrm{pmol} / \mu \mathrm{l})$, and $1 \mu \mathrm{l}$ of ReverTra Ace, volume-topped by RNase-free $\mathrm{H}_{2} \mathrm{O}$. Incubation proceeded at $42^{\circ} \mathrm{C}$ for 20 min in a PCR machine and heat applied at $99^{\circ} \mathrm{C}$ for 5 min. All synthesized cDNA samples were stored at $-20^{\circ} \mathrm{C}$. For the quantitative real time polymerase chain reaction (qRT-PCR), the SYBR Green Realtime PCR Master Mix (Toyobo) was used; the sample reaction volume $(20 \mu \mathrm{l})$ consisted of $1 \mu \mathrm{l}$ of 50 dilutions of cDNA, $10 \mu \mathrm{l}$ of SYBR Green, and $1 \mu \mathrm{l}$ of $p h l G \_$RT forward primer, and $1 \mu \mathrm{l}$ of $p h l G_{-} \mathrm{RT}$ reverse primer (Supplementary Table 1). The internal control for this experiment used $u b c$, sand housekeeping genes, for which the reaction volume was the same as above. Reverse transcription was performed by a thermocycler (Bio-Rad, Hercules, CA, USA) with these conditions: initial denaturation step at $95^{\circ} \mathrm{C}$ for $1 \mathrm{~min}, 44$ cycles at $95^{\circ} \mathrm{C}$ for $15 \mathrm{~s}, 56^{\circ} \mathrm{C}$ for $15 \mathrm{~s}$, for $72^{\circ} \mathrm{C}$ for $30 \mathrm{~s}$, $95^{\circ} \mathrm{C}$ for $10 \mathrm{~s}$, and $55^{\circ} \mathrm{C}$ for $5 \mathrm{~s}$, followed by a dissociation curve analysis. This experiment had three replicates per treatment. Relative gene expression levels were determined by the averaged fold-change (Pfaffl, 2004), calculated by dividing the ${ }^{\Delta \Lambda} \mathrm{Ct}$ of the selected plants (D16, H2) by the ${ }^{\Delta \Delta} \mathrm{Ct}$ of the wild-type Col-0. The phlG gene-relative expression was quantified for the internal control genes.

DAPG treatment and ISR analysis. Three-week-old plants were used to identify ISR activity by DAPG. Before a pathogen's inoculation, the plants were treated with water, methanol (DAPG solvent), and various concentrations of DAPG $(10,100$, or $200 \mu \mathrm{M})$. The DAPG stocks $(10$, $100,200 \mathrm{mM}$ ) were dissolved in methanol to their final concentration, and then further diluted with sterile water (200 $\mathrm{ml}$ ) so the same volume (i.e., 1,000-fold dilution, 200 $\mu 1)$ of methanol could be added to each solution individually. For the DAPG-priming treatment, DAPG was dissolved in water and $13 \mathrm{ml}$ of it applied onto the plant root via a needleless syringe. The same procedure was applied 
but with methanol $(0.1 \%)$, as the experimental control. After 2 days, two challenging pathogens (B. cinerea and Pst DC3000) were introduced. For $B$. cinerea, its spores $\left(5 \mu \mathrm{l}, 1 \times 10^{5} \mathrm{cfu} / \mathrm{ml}\right)$ were placed on $A$. thaliana leaves in three treatment groups: untreated control, DAPG nonpriming plus $B$. cinerea inoculation, and DAPG priming plus Botrytis inoculation. For Pst DC3000, its suspension (2 $\mathrm{ml}, 1 \times 10^{7} \mathrm{cfu} / \mathrm{ml}$ ) was sprayed onto the leaves, likewise in three treatment groups: untreated control plant, DAPG nonpriming plus Pst DC3000 inoculation, and DAPG priming plus $P_{s t} \mathrm{DC} 3000$ inoculation. All treated plants were incubated for 4 days, covered on a tray, at $22^{\circ} \mathrm{C}$ and $95 \%$ relative humidity under 12 -h/12-h light/dark conditions in the chamber. The extent of $B$. cinerea infection was gauged by measuring leaf necrosis diameters $(\mathrm{mm})$ in ImageJ. For Pst DC3000 infection, experimental Arabidopsis leaf samples were collected from 0 to 4 days, from 0.1 -g leaf material ( 0.1 g) were sterilized by $70 \%$ ethanol and washed thrice with distilled water. Each sample was homogenized using a mortar and pestle with $10 \mathrm{mM} \mathrm{MgCl}$, and a suitable dilution then plated onto King's medium B agar containing 100 $\mu \mathrm{g} / \mathrm{ml}$ of cycloheximide and $50 \mu \mathrm{g} / \mathrm{ml}$ of rifampicin (Pieterse et al., 1998). These plates were incubated at $27^{\circ} \mathrm{C}$ for 2 days after formed colonies were counted for bacterial cell density $(\mathrm{cfu} / \mathrm{ml})$. This value was compared among treatment groups by Duncan's new multiple range test (MRT) $(P<0.05)$. To confirm the differential disease symptoms in the wild-type, D16, and $\mathrm{H} 2$ plants, their harvested plant leaves were stained with trypan blue (Fernández-Bautista et al., 2016) by putting them directly onto plates containing this staining solution $(10 \mathrm{ml}$ of lactic acid, $10 \mathrm{ml}$ of phenol, $10 \mathrm{ml}$ of glycerol, $10 \mathrm{ml}$ of distilled water, with 40 $\mathrm{mg}$ of trypan blue). After 1-h incubation, each solution was removed and refilled with $100 \%$ ethanol. The solution was removed after $24 \mathrm{~h}$ and refilled with a $60 \%$-glycerol solution, and the staining then visualized.

Relative expression of SA- and JA/ET-related defense genes. To identify the difference in ISR-related genes' expression between $A$. thaliana Col- 0 and $p h l G$ transgenic lines (D16, H2), qRT-PCR was performed with known ISR marker genes (i.e., for SA/JA/ET signaling). $100 \mu \mathrm{M}$ of DAPG was applied to roots for 2 days prior to the challenge from pathogens ( $2 \mathrm{ddt}$, day-post-DAPG-treatment), after which the pathogens were introduced and allowed to incubate for 4 days. RNA was extracted from Arabidopsis leaves and cDNA was synthesized from $2 \mu \mathrm{g}$ of total RNA. Five genes in all were examined for the expression of JA/ ET signaling (i.e., WRKY11, PDF1.2) and SA signaling (i.e., EDS5, PR1, PR2) (Journot-Catalino et al., 2006;
Wang et al., 2010). The same reference genes ( $S A N D$, $U B C$ ) were used to quantify gene expression patterns (Czechowski et al., 2005). All primers' information can be found in Supplementary Table 1.

\section{Results}

DAPG inhibits $A$. thaliana Col-0 seed germination and growth. DAPG's phytotoxicity to $A$. thaliana Col-0 was verified and its concentration that inhibits seed germination also determined. For the untreated control, $100 \%$ of its seeds had germinated at 2 days. Germination, however, decreased markedly depending on the DAPG concentration (Supplementary Fig. 1B). At 80 or $100 \mu \mathrm{M}$ DAPG concentrations, all seeds did not germinate until 10 days later. This delay was statistically distinguishable from the other treatments (control, $20 \mu \mathrm{M}, 40 \mu \mathrm{M}, 60 \mu \mathrm{M}$ ) (Supplementary Table 2). Therefore, the final DAPG concentration for the selection of $p h l G$ transgenic Arabidopsis was set at 80 and $100 \mu \mathrm{M}$ for 10 days.

phlG-transgenic Arabidopsis shows tolerance against DAPG. The $p h l G$ gene was amplified using the phlGF and phlGR primers from the genomic DNA of $P$. fluorescens Q2-87 (Supplementary Table 1). Their PCR products were identified as an amplicon of 879-bp spanning the entire length of the phlG gene in P. fluorescens Q2-87 (Supplementary Fig. 2). The phlG fragment was successfully cloned into a donor vector (PCR8/GW/TOPO), and this clone validated by EcoRV and 365-bp and 3,331-bp restriction enzyme reactions (Supplementary Fig. 2). EcoRI confirmed the expression vector by the LR reaction for the entry vector and destination vector (pMDC43). The binary vector containing the $p h l G$ gene (Supplementary Fig. 1A) was transformed into $A$. thaliana Col-0 and selection of the phlG transgenic Arabidopsis lines $\left(\mathrm{T}_{1}\right)$ were achieved using 80 or $100 \mu \mathrm{M}$ of DAPG or $57 \mu \mathrm{M}$ hygromycin in MS media (Supplementary Fig. 1C and D). From the DAPG and hygromycin media, ca. 4,000 $\mathrm{T}_{1}$ lines were screened, resulting in total of 26 and 7 lines selected from each, respectively (Supplementary Table 3 ). The $\mathrm{T}_{1}$ selected plants were labeled D1-D26 (DAPG) and H1-H7 (hygromycin) and grown to obtain the next generation. These $T_{2}$ generation lines were tested by segregation analysis, which validated the presence of a single copy of the chromosomeflanking vector (Supplementary Table 4). Both DAPG and hygromycin selections yielded similar results. The D16 line has been described as DAPG-tolerant for 144 plants and DAPG-sensitive for 45 plants. By way of comparison, 178 plants flourished in the hygromycin medium, and 58 plants 
were bleached out as sensitive lines. The DAPG-tolerant plants in the $\mathrm{H} 2$ line had 132 progenies of which 50 were prone to DAPG. In the hygromycin media, 90 plants were selected from the $\mathrm{H} 2$ line of which 31 plants were not resistant to hygromycin. Thus phenotype segregation ratio was 3:1, which was confirmed statistically (chi-square test; $P<$ 0.05 ) (Supplementary Table 4). This experiment was done three times, all producing similar results.

Detection of the phlG inserted gene in the $\mathrm{D} 16$ and $\mathrm{H} 2$ lines. Genomic DNA (gDNA) and complementary DNA (cDNA) from the selected $p h l G$ transgenic lines, D16 and $\mathrm{H} 2$ were prepared. Both no DNA (blank) and nontransgenic $A$. thaliana Col-0 DNA served as the negative controls. Genomic DNA of P. fluorescens Q2-87 was a positive control. The blank sample, and DNA of the wildtype $A$. thaliana Col- 0 were not amplified in $p h l G$, in either the gDNA or cDNA, by PCR. Samples of $P$. fluorescens Q2-87, D16, and H2 demonstrated amplification of the $p h l G$ gene in both their gDNA (879-bp) and cDNA (157bp) (Supplementary Fig. 3A and B). However, in A. thaliana Col-0 $\mathrm{C}_{\mathrm{q}}$ value of the $p h l G$ gene was undetectable. The D16 line showed that $p h l G$ expression was 256.3-fold $(U B C)$ and 270.9-fold (SAND) greater when compared when $A$. thaliana Col-0. For $\mathrm{H} 2$ line, phl $G$ was expressed at 74.8-fold $(U B C)$ and 49.6-fold $(S A N D)$ greater levels (Supplementary Fig. 3C). These results confirmed the D16 line had higher $p h l G$ expression than did the $\mathrm{H} 2$ line, a difference that was significant according to Duncan's new MRT $(P<0.05)$.

Phenotype of $A$. thaliana Col-0, D16 and H2. To assess whether the phenotypes of $A$. thaliana Col-0, D16, and $\mathrm{H} 2$ differed, their growth was observed between 15 and 21 days. At 15 days, the fresh weight of $A$. thaliana Col0 was $29.5 \mathrm{mg}, 31.0 \mathrm{mg}$ for D16, and $30.4 \mathrm{mg}$ for H2. For A. thaliana Col- 0 , its primary root's length was $40.6 \mathrm{~mm}, 41.3$ $\mathrm{mm}$ for D16, and $40.5 \mathrm{~mm}$ for H2 (Supplementary Fig. 4A, $\mathrm{C}$ and $\mathrm{D}$ ). Fresh weight recorded at 21 days (rosette stage) was $111.8 \mathrm{mg}$ for A. thaliana Col-0, $115.9 \mathrm{mg}$ for D16, and $116.3 \mathrm{mg}$ for $\mathrm{H} 2$, with corresponding leaf areas of 4.1 $\mathrm{cm}^{2}, 3.8 \mathrm{~cm}^{2}$, and $4.2 \mathrm{~cm}^{2}$ (Supplementary Fig. 4B, E and F). There was no evidence of any distinction between plant phenotypes after repeated this experiment five times (Tukey HSD test, $P<0.05)$. These finding indicated that the D16 and $\mathrm{H} 2$ are sufficient for further ISR research.

DAPG-primed $A$. thaliana Col-0 is resistant against $\boldsymbol{B}$. cinerea and Pst DC3000. For this experiment, a necrotrophic fungal pathogen (B. cinerea) and a biotrophic bacterial pathogen (Pst DC3000) were used to evaluate ISR development in DAPG-primed A. thaliana Col-0 plants. Upon DAPG-priming, the $B$. cinerea-inoculated plants with disease symptoms had lesion diameters that were $0 \mathrm{~mm}$ at
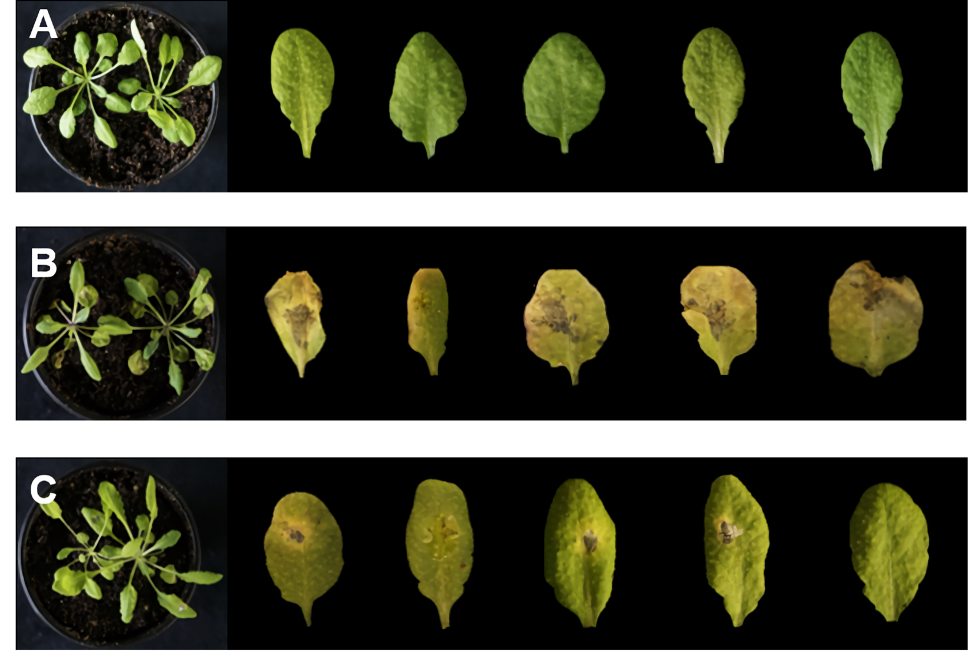

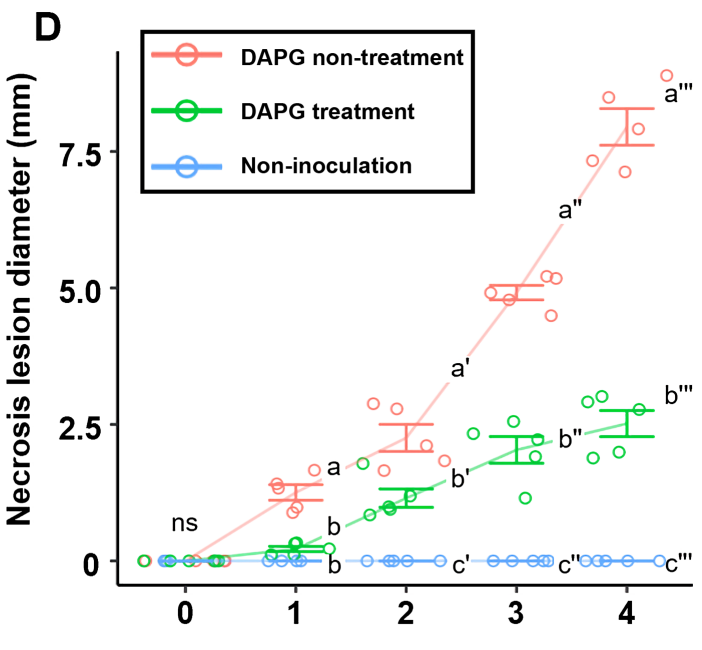

Days post $B$. cinerea inoculation (dpi)

Fig. 1. Induction of disease resistance against Botrytis cinerea via 2,4-diacetylphloroglucinol (DAPG)-priming in Arabidopsis. Arabidopsis roots were treated with $13 \mathrm{ml}$ of DAPG $(100 \mu \mathrm{M})$ solution administered to them with a needleless syringe. Two days after applying the DAPG treatment, the leaves were inoculated with Botrytis cinerea spores $\left(1 \times 10^{5}\right.$ colony-forming unit/ml $)$ or left uninfected. Necrosis lesion diameter was measured at 4 dpi. (A) Uninfected control. (B) Pathogen infection after sterile water treatment of roots. (C) Pathogen infection after the DAPG-priming treatment of roots. (D) Necrosis lesion diameter under each condition. Bars are standard deviations of the means. Bars with different letters are significant different $(P<0.05)$ based on ANOVA analysis. 

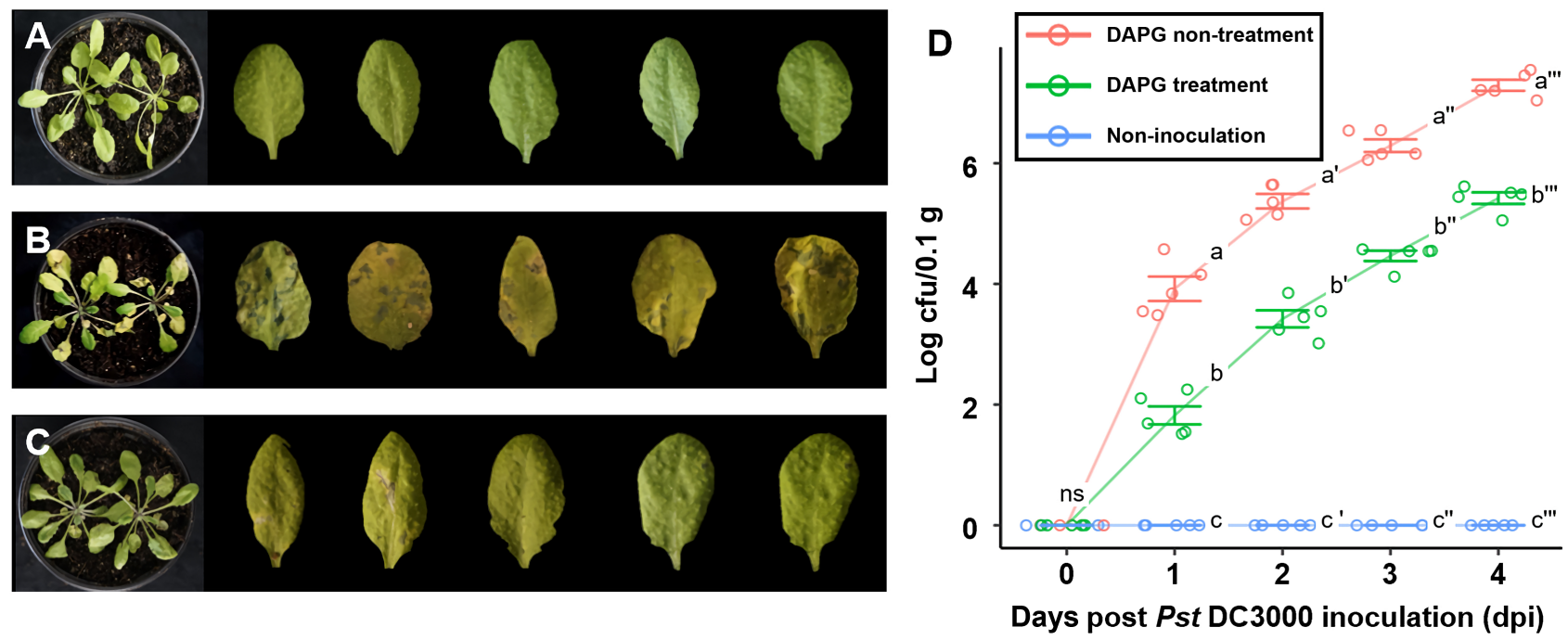

Fig. 2. Induction of disease resistance against Pst DC3000 via 2,4-diacetylphloroglucinol (DAPG)-priming in Arabidopsis thaliana. DAPG $(100 \mu \mathrm{M})$ pretreatment was achieved with a 13-ml solution applied onto the roots of plants with a needleless syringe. Two days after the DAPG treatment, Pst DC3000 at $1 \times 10^{7}$ colony-forming unit (cfu)/ml was sprayed onto the leaves or plants were left non-inoculated. Bacterial density was observed for 4 dpi. (A) No pathogen/no DAPG-primed control. (B) Pathogen and sterile water treatment. (C) Pathogen treatment on DAPG-primed plant. (D) Bacterial cell density assays in Arabidopsis. Bars are standard deviations of the means. Bars are standard deviations of the means. Bars with different letters are significant different $(P<0.05)$ according to Duncan's new multiple range test based on ANOVA analysis.

0 day post inoculation (dpi), $0.2 \mathrm{~mm}$ at $1 \mathrm{dpi}, 1.1 \mathrm{~mm}$ at $2 \mathrm{dpi}, 2 \mathrm{~mm}$ at $3 \mathrm{dpi}$, and $2.5 \mathrm{~mm}$ at $4 \mathrm{dpi}$. By contrast, in non-primed plants, their necrosis lesion diameters were 0 $\mathrm{mm}$ at $0 \mathrm{dpi}, 1.2 \mathrm{~mm}$ at $1 \mathrm{dpi}, 2.2 \mathrm{~mm}$ at $2 \mathrm{dpi}, 4.9 \mathrm{~mm}$ at $3 \mathrm{dpi}$, and $7.9 \mathrm{~mm}$ at 4 dpi (Fig. 1). After DAPG-priming, the Pst DC3000-challenged plants could recognize bacterial cell densities ( $\log \mathrm{cfu} / 0.1 \mathrm{~g}$ of leaves) of 0 at $0 \mathrm{dpi}, 1.8$ at $1 \mathrm{dpi}, 3.4$ at $2 \mathrm{dpi}, 4.4$ at $3 \mathrm{dpi}$, and 5.4 at $4 \mathrm{dpi}$. The Pst DC3000 density in DAPG non-primed plants were 0 at 0 dpi, 1.2 at $1 \mathrm{dpi}, 2.2$ at $2 \mathrm{dpi}, 4.9$ at $3 \mathrm{dpi}$, and 7.9 at 4 dpi, respectively (Fig. 2). Together, these findings indicated that DAPG-priming of $A$. thaliana increased its ISR activity against both fungal and bacterial pathogens.

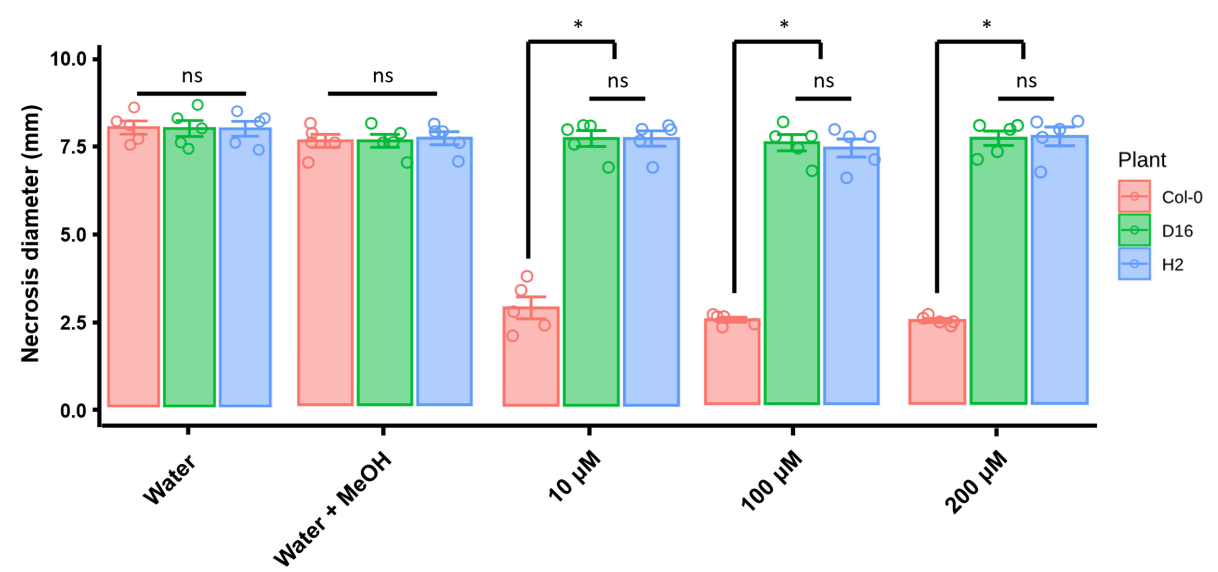

Fig. 3. Disease severity in 2,4-diacetylphloroglucinol (DAPG)-primed Arabidopsis thaliana Col-0 and the phlG transgenic line (D16, H2). For 21-day-old plants, their roots were treated water, methanol $(0.1 \%)$, or DAPG $(10,100$, and $200 \mu \mathrm{M})$ and then inoculated in the growth chamber under 12 -h/12-h, light/dark condition at $22^{\circ} \mathrm{C}, 60 \%$ relative humidity, for 2 days. Then, Botrytis cinerea spores $\left(1 \times 10^{5}\right.$ $\mathrm{cfu} / \mathrm{ml})$ were applied to plants; the latter were inoculated for 4 days in a growth chamber under $22^{\circ} \mathrm{C}, 95 \%$ relative humidity. Necrosis diameters were measured at 4 days post-inoculation. Bars represent the standard error of the mean. Statistically significant differences $(P$ $<0.05$ ) are indicated by an asterisk (*). 'ns' denotes no statistical significance. 


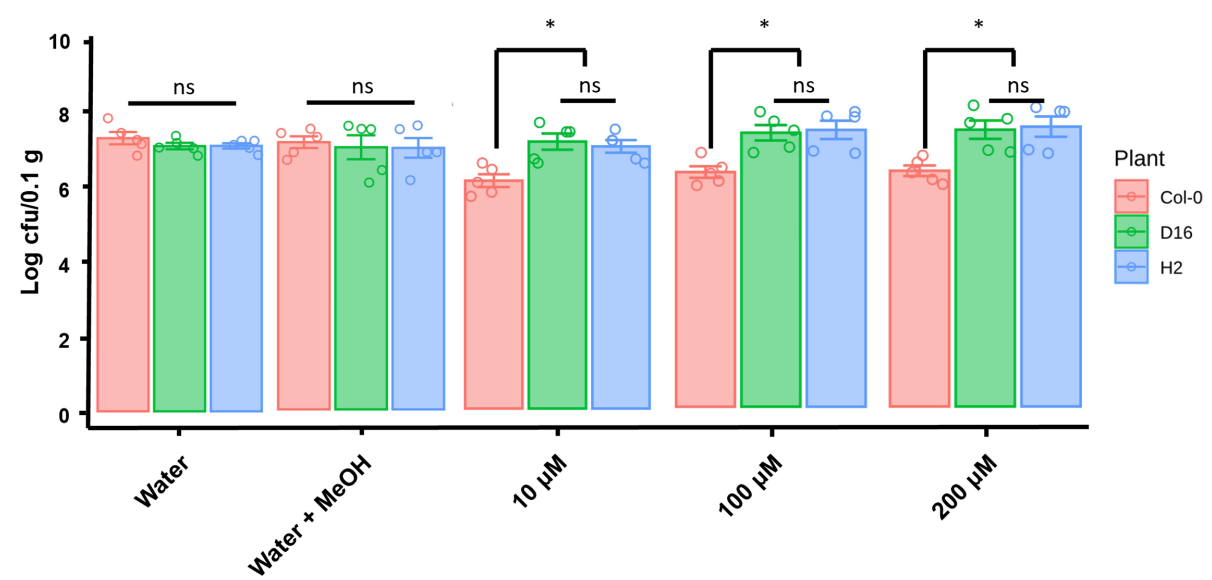

Fig. 4. Disease severity in 2,4-diacetylphloroglucinol (DAPG)-primed Arabidopsis thaliana Col0 and phlG transgenic lines (D16, H2). For 21-day-old plants, their roots were treated water, methanol $(0.1 \%)$, or DAPG $(10,100$, and $200 \mu \mathrm{M})$ and then inoculated in the growth chamber under $12-\mathrm{h} / 12-\mathrm{h}$, light/dark cycle condition at $22^{\circ} \mathrm{C}, 60 \%$ relative humidity, for 2 days. Then, Pst DC3000 $\left(1 \times 10^{8}\right.$ colony-forming unit [cfu] $/ \mathrm{ml}$ ) was sprayed onto plants; the latter were inoculated for 4 days in a growth chamber under $95 \%$ relative humidity (same as above for other conditions). The density of Pst DC3000 in the leaves was measured at 4 days post-inoculation. Bars represent the standard error of the mean. Statistically significant differences $(P<0.05)$ are indicated by an asterisk $(*)$. 'ns' denotes no statistical significance.

phlG transgenic D16 and H2 failed DAPG mediated ISR. DAPG functioning for ISR was investigated in the A. thaliana Col-0, D16, and $\mathrm{H} 2$ plants by apply different concentrations of DAPG $(10,100$, and $200 \mu \mathrm{M})$. In the absence of DAPG treatment, all transgenic and non-transgenic plants showed similar disease symptoms and lesion diameters (Fig. 3). The mock treatment ( $0.1 \%$ methanol, DAPG solvent) slightly enhanced disease resistance of both non-transgenic (Col-0) and transgenic (D16 and H2) Arabidopsis against $B$. cinerea infection. Importantly, the DAPG-primed $A$. thaliana Col-0 showed significantly reduced the disease symptoms when compared with those of non-primed plants. The lesion diameters were 2.5, 2.4, and $2.4 \mathrm{~mm}$ in 10,100 , and $200 \mu \mathrm{M}$ DAPG-treated plants, respectively. Conversely, DAPG-treated D16 and H2 plants experienced similar effects to those from water and methanol treatments. Under all three concentrations of DAPG, the lesion diameters were $7 \mathrm{~mm}$ in D16 plants, very similar to the $7.1 \mathrm{~mm}$ measured in DAPG-primed $\mathrm{H} 2$ plants.

The non-primed $A$. thaliana Col-0, D16, and $\mathrm{H} 2$ plants harbored similar cell densities of Pst DC3000 bacterial pathogen (>7 log cfu/0.1 g of leaves) (Fig. 4). In DAPGprimed $A$. thaliana Col-0, the pathogen density was 6.4 (Col-0), 6.8 (D16), and 6.5 (H2) $\log \mathrm{cfu} / 0.1 \mathrm{~g}$ of leaves per 10,100 , and $200 \mu \mathrm{M}$ of DAPG, respectively. However, the DAPG-primed D16 and H2 failed to trigger their ISR and were unable to suppress the Pst DC3000 pathogen densities: these were 6.4 (10 $\mu \mathrm{M}$ DAPG), 6.3 (100 $\mu \mathrm{M}$ DAPG), and $6.2(200 \mu \mathrm{M}$ DAPG) in D16 and $6.5(10 \mu \mathrm{M}$ DAPG),
$6.1(100 \mu \mathrm{M}$ DAPG $)$, and $6.8(200 \mu \mathrm{M}$ DAPG $)$ in $\mathrm{H} 2$.

These results were confirmed by analyzing the infected cells with trypan blue staining, which let cell deaths be visualized (Keogh et al., 1980). The D16 and H2 leaves presented more stained areas than did wild-type $A$. thaliana Col-0 after treatment with $100 \mu \mathrm{M}$ of DAPG (Supplementary Fig. 5). In sum, these results showed $p h l G$-transgenic plants were unable to activate the DAPG-mediated defense system against both necrotrophic and biotrophic pathogens.

DAPG triggers the JA/ET-mediated defense system. SA-mediated defense (EDS5, PR1, PR2), JA/ET-mediated defense (WRKY11, PDF1.2) or SA, JA integrated signaling (WRKY70) were assessed to establish the induced defense signal pathway (Jiang et al., 2016; Li et al., 2004). The respective expression levels of these five genes were assessed from 0 to 6 ddt by qRT-PCR (Figs. 5, 6). The $B$. cinerea inoculation of the DAPG-primed Col-0 led to upregulation of PDF1.2 and WRKY70 compared with the D16, H2 plants, at both 5 and 6 ddt (Student $t$-test, $P<0.05$ ) (Fig. 5). By contrast, the wild-type $A$. thaliana Col-0 and phlG transgenic D16 and $\mathrm{H} 2$ plants all showed a similar expression of the SA-mediated defense genes.

The $A$. thaliana Col-0 plants inoculated with Pst DC3000 after treatment with DAPG showed no difference in their gene expression levels of WRKY11, EDS5, PR1, and PR2 when compared to those of D16 and $\mathrm{H} 2$, but there was a difference in the expression of WRKY70 and PDF1.2 genes (Fig. 6). At 4 ddt, different gene expression activity was 


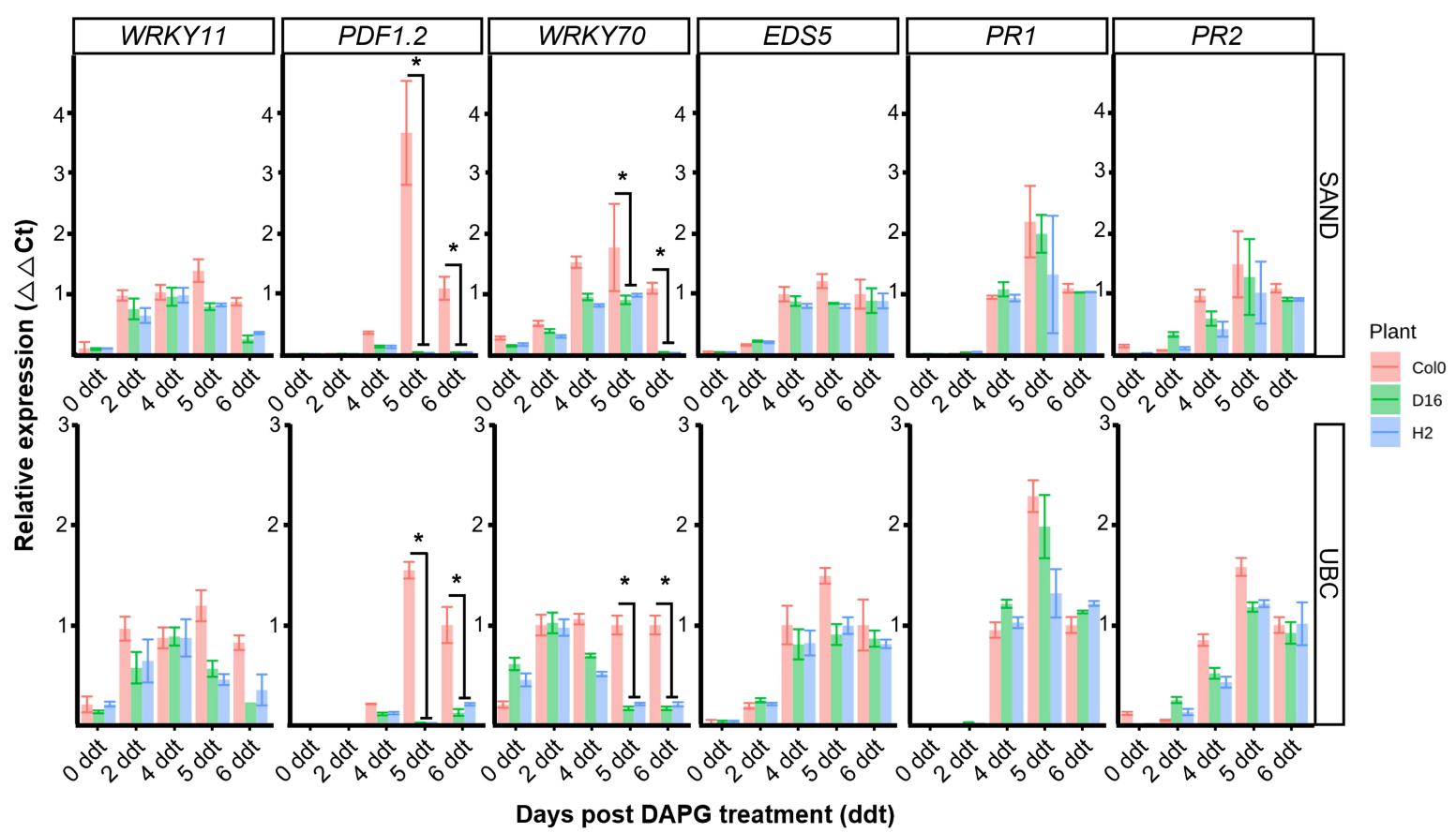

Fig. 5. Salicylic acid and jasmonic acid/ethylene signaling genes' expression in Arabidopsis thaliana Col-0, D16, and H2 plants after challenging them with a fungal pathogen. 2,4-Diacetylphloroglucinol (DAPG, $100 \mu \mathrm{M}$ ) was applied onto roots and plants inoculated for 2 days later. Then, Botrytis cinerea spores $\left(1 \times 10^{5}\right.$ colony-forming unit $\left.[\mathrm{cfu}] / \mathrm{ml}\right)$ were applied as a droplet of spore stock $(5 \mu \mathrm{l})$ onto the leaves. Leaves were harvested at the indicated time points to extract their total RNA. Relative expression levels per gene were determined by quantitative real time polymerase chain reaction. All experiments were performed three times. Statistically significant differences $(P<0.05)$ between mean values are indicated by an asterisk $(*)$. The bars are standard deviations.

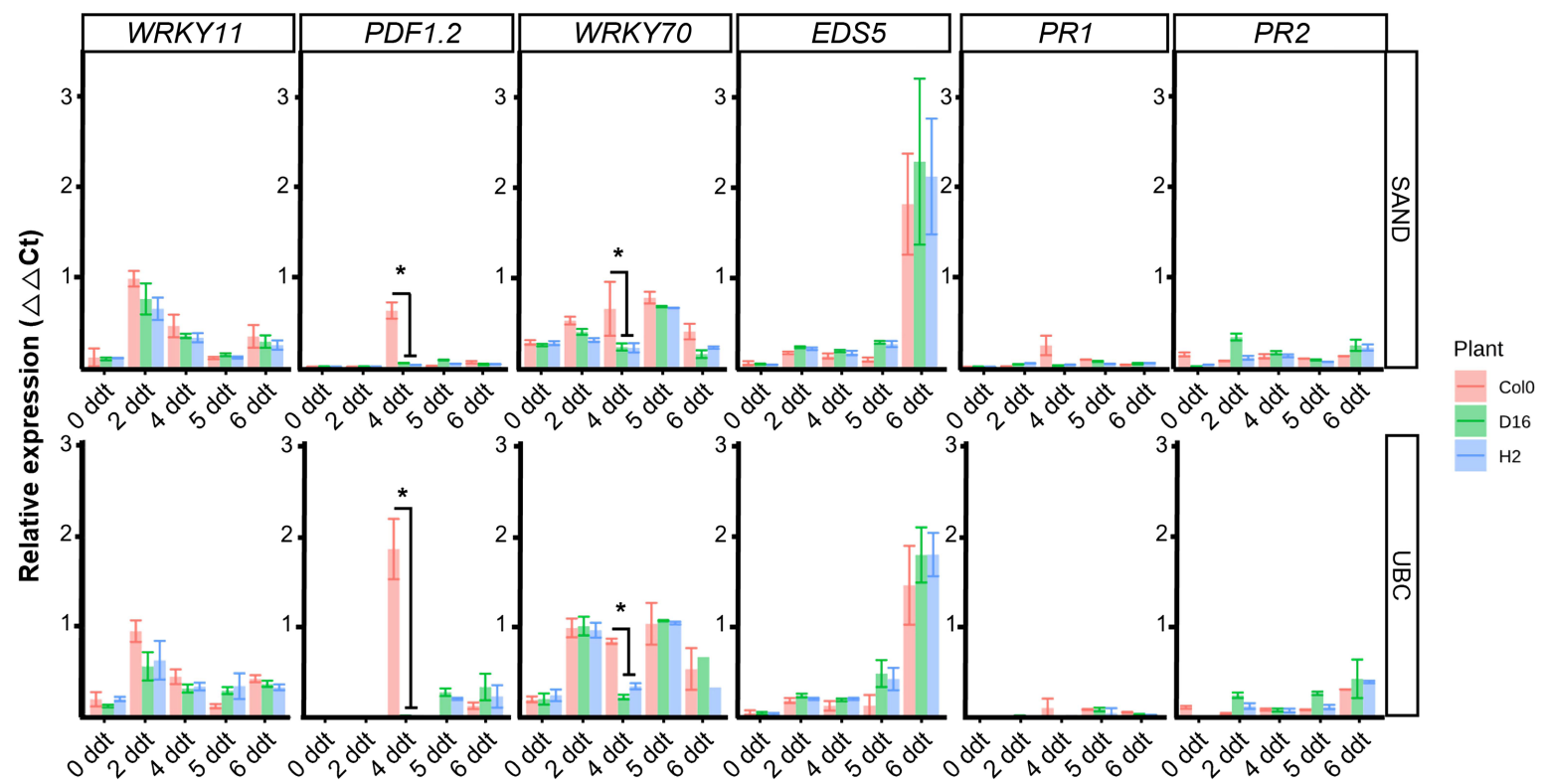

Days post DAPG treatment (ddt)

Fig. 6. Salicylic acid and jasmonic acid/ethylene signaling genes' expression in Arabidopsis thaliana Col-0, D16, and H2 plants after challenging them with a bacterial pathogen. 2,4-Diacetylphloroglucinol (DAPG, $100 \mu \mathrm{M}$ ) was applied onto roots and plants inoculated for 2 days later. Then, Pst DC3000 $\left(1 \times 10^{7} \mathrm{cfu} / \mathrm{ml}\right)$ was sprayed onto plants, using $2 \mathrm{ml}$ per plant. Leaves were harvested at the indicated time points to extract their total RNA. Relative expression levels per gene were determined by quantitative real time polymerase chain reaction. All experiments were performed three times. Statistically significant differences $(P<0.05)$ between mean values are indicated by an asterisk (*). The bars are standard deviations. 
observed and $P D F 1.2$ was not expressed in D16 and H2 lines (Student $t$-test, $P<0.05$ ). Similarly, at $4 \mathrm{ddt}, W R K Y 70$ gene expression was statistically higher in the $A$. thaliana Col-0 than either D16 or H2 (Student $t$-test, $P<0.05$ ). Interestingly, expression levels of the SA-mediated defense genes (EDS5, PR1, PR2) were similar between Col-0, D16, and $\mathrm{H} 2$ plants.

\section{Discussion}

DAPG has a wide range of antibiotic activities capable of killing bacteria, fungi, nematodes, and even plants. It is known that DAPG prevents seed germination and plants' growth (Keel et al., 1992), and that it can alter root architecture by interacting with the auxin-dependent signaling pathway (Brazelton et al., 2008). The phlG gene encodes DAPG hydrolase, which can catalyze non-toxic MAPG in the DAPG biosynthetic loci of $P$. fluorescens (Bottiglieri and Keel, 2006). DAPG-producing P. fluorescens harbor antibiotic resistance depending on the action of this hydrolase. In our study, the $p h l G$ gene was transformed into $A$. thaliana Col- 0 and we selected the DAPG-degrading plant lines to comprehensively investigate the roles of DAPG in the plant ISR mechanism.

Root-colonizing P. fluorescens CHA0, a biological control agent producing DAPG, successfully protected A. thaliana from infection with Hyaloperonospora arabidopsidis by altering its ISR defense system (Iavicoli et al., 2003). The same CHA0 strain also defended this plant against Meloidogyne javanica, a root-knot nematode (Siddiqui et al., 2007). To better understand the mechanism and participation of DAPG in ISR, some studies have relied on testing responses of pathway-related mutants with a single or double mutant Arabidopsis line, mainly with respect to SA or JA/ET hormone signaling. SA is usually involved in processes confering resistance to biotrophic pathogens while JA/ET activity contributed to resistance against necrotrophic pathogens (Lievens et al., 2017). Both SA, JA signaling-deficient mutants of Arabidopsis were reportedly more vulnerable to $B$. cinerea and $P s t$ DC3000 than wild-type plants (Jiang et al., 2016; Nie et al., 2017). Nevertheless, other physiological functions in plant growth involve these hormones. For example, SA shapes phenotypic features, such as the numbers of cotyledons and rumpled leaves, while the JA/ET hormones influence root phenotypic development, namely primary root, lateral root, and root hair characteristics, as well as also hypocotyl weight, apical hook, and plant height (Peng et al., 2009). Such reports point to many phenotypic imbalances arising in mutant Arabidopsis lines, so it may be inappropriate to use a hormone related mutant for studying the plant's ISR function against pathogens. A way around this problem is to use insensitive transgenic plant lines of DAPG (D16, $\mathrm{H} 2$ ), which as confirmed here have no phenotypic distinctions from wild-type counterparts. Furthermore, the Col0 , D16, and $\mathrm{H} 2$ treated with water showed no difference in their responses to B. cinerea and Pst DC3000. However, DAPG-primed D16 and H2 showed significantly greater disease severity and higher pathogen cell density than did the DAPG-primed wild-type plant. This result indicates the $p h l G$ transgenic plants were not able to induce a defense system because of DAPG catalysis.

In DAPG-primed plants, the expression levels of $P D F 1.2$, and $W R K Y 70$ were lower in the $\mathrm{D} 16$ and $\mathrm{H} 2$ than Col-0 following infection with either $B$. cinerea or Pst DC3000. But levels of expression for SA's EDS5, PR1, and $P R 2$ genes were not specific to D16, $\mathrm{H} 2$, or wild-type plants. These results suggest the JA/ET signaling pathway plays a more critical role in plants' ISR activated by DAPG than does the SA-based pathway. In other work, $P$. fluorescens CHA0 could not mount mediated resistance to Peronospora parasitica in the Arabidopsis mutants nprl1, jar1-1, and eirl-1 (Lavicoli et al., 2007). In that study, synthetic DAPG, for comparison, also failed to trigger induced resistance response on the Arabidopsis mutants eir 1 and jarl. Similarly, P. fluorescens Q2-87 failed to defend Pst DC3000 against the npr 1-1, jarl, and etr 1 mutants (Weller et al., 2012). Those findings suggested that DAPGmediated ISR relied on the signal pathway based on JA/ ET, which is consistent with our results.

In conclusion, DAPG-hydrolyzing plants showed tolerance against toxicity to DAPG and JA/ET defense system plays a critical role in the DAPG-mediated mechanism of ISR. These observations made from using $p h l G$-transgenic plants in experimental investigations of the ISR system provide more clear proof of how plant-microbe interactions can operate.

\section{Acknowledgments}

This research was supported by the Basic Science Research Program of the National Research Foundation of Korea (NRF) funded by the Ministry of Education (2020R1A2C2004177).

\section{Electronic Supplementary Material}

Supplementary materials are available at The Plant Pathology Journal website (http://www.ppjonline.org/). 


\section{References}

Beckers, G. J. and Conrath, U. 2007. Priming for stress resistance: from the lab to the field. Curr. Opin. Plant Biol. 10:425-431.

Boller, T. and Felix, G. 2009. A renaissance of elicitors: perception of microbe-associated molecular patterns and danger signals by pattern-recognition receptors. Annu. Rev. Plant Biol. 60:379-406.

Bottiglieri, M. and Keel, C. 2006. Characterization of phlG, a hydrolase that specifically degrades the antifungal compound 2,4-diacetylphloroglucinol in the biocontrol agent Pseudomonas flourescens CHA0. Appl. Environ. Microbiol. 72:418427.

Brazelton, J. N., Pfeufer, E. E., Sweat, T. A., Gardener, B. B. M. and Coenen, C. 2008. 2,4-diacetylphloroglucinol alters plant root development. Mol. Plant-Microbe Interact. 21:13491358.

Cao, H., Glazebrook, J., Clarke, J. D., Volko, S. and Dong, X. 1997. The Arabidopsis NPR1 gene that controls systemic acquired resistance encodes a novel protein containing ankyrin repeats. Cell 88:57-63.

Clough, S. J. and Bent, A. F. 1998. Floral dip: a simplified method for Agrobacterium-mediated transformation of Arabidopsis thaliana. Plant J. 16:735-743.

Czechowski, T., Stitt, M., Altmann, T., Udvardi, M. K. and Scheible, W.-R. 2005. Genome-wide identification and testing of superior reference genes for transcript normalization in Arabidopsis. Plant Physiol. 139:5-17.

Dempsey, D. A. and Klessig, D. F. 2012. SOS - too many signals for systemic acquired resistance? Trends Plant Sci. 17:538545.

Edwards, K., Johnstone, C. and Thompson, C. 1991. A simple and rapid method for the preparation of plant genomic DNA for PCR analysis. Nucleic Acids Res. 19:1349.

Engelberth, J., Alborn, H. T., Schmelz, E. A. and Tumlinson, J. H. 2004. Airborne signals prime plants against insect herbivore attack. Proc. Natl. Acad. Sci. U. S. A. 101:1781-1785.

Fernández-Bautista, N., Domínguez-Núñez, J. A., Moreno, M. M. C. and Berrocal-Lobo, M. 2016. Plant tissue trypan blue staining during phytopathogen infection. Bio-Protocol 6:e2078.

Haas, D. and Keel, C. 2003. Regulation of antibiotic production in root-colonizing Pseudomonas spp. and relevance for biological control of plant disease. Annu. Rev. Phytopathol. 41:117-153.

Iavicoli, A., Boutet, E., Buchala, A. and Métraux, J.-P. 2003. Induced systemic resistance in Arabidopsis thaliana in response to root inoculation with Pseudomonas fluorescens CHA0. Mol. Plant-Microbe Interact. 16:851-858.

Jiang, C.-H., Fan, Z.-H., Xie, P. and Guo, J.-H. 2016. Bacillus cereus AR156 Extracellular Polysaccharides Served as a Novel Micro-associated Molecular Pattern to Induced Systemic Immunity to Pst DC3000 in Arabidopsis. Front. Microbiol.
7:664.

Jiang, C.-H., Huang, Z.-Y., Xie, P., Gu, C., Li, K., Wang, D.-C., Yu, Y.-Y., Fan, Z.-H., Wang, C.-J., Wang, Y.-P., Guo, Y.-H. and Guo, J.-H. 2016. Transcription factors WRKY70 and WRKY11 served as regulators in rhizobacterium Bacillus cereus AR156-induced systemic resistance to Pseudomonas syringae pv. tomato DC3000 in Arabidopsis. J. Exp. Bot. 67:157-174.

Journot-Catalino, N., Somssich, I. E., Roby, D. and Kroj, T. 2006. The transcription factors WRKY11 and WRKY17 act as negative regulators of basal resistance in Arabidopsis thaliana. Plant Cell 18:3289-3302.

Keel, C., Schnider, U., Maurhofer, M., Voisard, C., Laville, J., Burger, U. Wirthner, P., Hass, D. and Défago, G. 1992. Suppression of root diseases by Pseudomonas fluorescens CHA0: importance of the bacterial secondary metabolite 2,4-diacetylphloroglucinol. Mol. Plant-Microbe Interact. 5:4-13.

Keogh, R. C., Deverall, B. J. and McLeod, S. 1980. Comparison of histological and physiological responses to Phakopsora pachyrhizi in resistant and susceptible soybean. Trans. Br. Mycol. Soc. 74:329-333.

Koo, Y. M., Heo, A. Y. and Choi, H. W. 2020. Salicylic acid as a safe plant protector and growth regulator. Plant Pathol. J. 36:1-10.

Kwak, Y.-S. and Weller, D. M. 2013. Take-all of wheat and natural disease suppression: a review. Plant Pathol. J. 29:125135.

Li, J., Brader, G. and Palva, E. T. 2004. The WRKY70 transcription factor: a node of convergence for jasmonate-mediated and salicylate-mediated signals in plant defense. Plant Cell 16:319-331.

Lievens, L., Pollier, J., Goossens, A., Beyaert, R. and Staal, J. 2017. Abscisic acid as pathogen effector and immune regulator. Front. Plant Sci. 8:587.

Nie, P., Li, X., Wang, S., Guo, J., Zhao, H. and Niu, D. 2017. Induced systemic resistance against Botrytis cinerea by $B a$ cillus cereus AR156 through a JA/ET- and NPR1-dependent signaling pathway and activates PAMP-triggered immunity in Arabidopsis. Front. Plant Sci. 8:238.

Pfaffl, M. W. 2004. Quantification strategies in real-time PCR. In: A-Z of quantitative PCR, ed. by S. A. Bustin, pp. 87-112. International University Line, La Jolla, CA, USA.

Peng, Z. Y., Zhou, X., Li, L., Yu, X., Li, H., Jiang, Z., Cao, G., Bai, M., Wang, X., Jiang, C., Lu, H., Hou, X., Qu, L., Wang, Z., Zuo, J., Fu, X., Su, Z., Li, S. and Guo, H. 2009. Arabidopsis Hormone Database: a comprehensive genetic and phenotypic information database for plant hormone research in Arabidopsis. Nucleic Acids Res. 37 Suppl 1:D975-D982.

Pieterse, C. M., van Wees, S. C., van Pelt, J. A., Knoester, M., Laan, R., Gerrits, H., Weisbeek, P. J., and van Loon, L. C. 1998. A novel signaling pathway controlling induced systemic resistance in Arabidopsis. Plant Cell 10:1571-1580.

Pieterse, C. M., Zamioudis, C., Berendsen, R. L., Weller, D. M., Van Wees, S. C. M. and Bakker, P. A. H. M. 2014. Induced 
systemic resistance by beneficial microbes. Annu. Rev. Phytopathol. 52:347-375.

Raaijmakers, J. M. and Weller, D. M. 2001. Exploiting genotypic diversity of 2,4-diacetylphloroglucinol-producing Pseudomonas spp.: characterization of superior root-colonizing $P$. fluorescens strain Q8r1-96. Appl. Environ. Microbiol. 67:25452554.

Seif El-Yazal, S. A., Seif El-Yazal, M. A., Dwidar, E. F. and Rady, M. M. 2015. Phytohormone crosstalk research: cytokinin and its crosstalk with other phytohormones. Curr. Protein Pept. Sci. 16:395-405.

Siddiqui, Z. A., Baghel, G. and Akhtar, M. S. 2007. Biocontrol of Meloidogyne javanica by Rhizobium and plant growthpromoting rhizobacteria on lentil. World J. Microbiol. Biotechnol. 23:435-441.

Stepanova, A. N., Hoyt, J. M., Hamilton, A. A. and Alonso, J. M. 2005. A link between ethylene and auxin uncovered by the characterization of two root-specific ethylene-insensitive mutants in Arabidopsis. Plant Cell 17:2230-2242.

Wang, C., Gao, F., Wu, J., Dai, J., Wei, C. and Li, Y. 2010. Arabidopsis putative deacetylase AtSRT2 regulates basal defense by suppressing PAD4, EDS5 and SID2 expression. Plant Cell
Physiol. 51:1291-1299.

van Wees, S. C. M., Luijendijk, M., Smoorenburg, I., van Loon, L. C. and Pieterse, C. M. J. 1999. Rhizobacteria-mediated induced systemic resistance (ISR) in Arabidopsis is not associated with a direct effect on expression of known defenserelated genes but stimulates the expression of the jasmonateinducible gene Atvsp upon challenge. Plant Mol. Biol. 41:537-549.

Weller, D. M., Landa, B. B., Mavrodi, O. V., Schroeder, K. L., De La Fuente, L., Blouin Bankhead, S., Allende Molar, R., Bonsall, R. F., Mavrodi, D. V. and Thomashow, L. S. 2007. Role of 2,4-diacetylphloroglucinol-producing fluorescent Pseudomonas spp. in the defense of plant roots. Plant Biol. 9:4-20.

Weller, D. M., Mavrodi, D. V., van Pelt, J. A., Pieterse, C. M. J., van Loon, L. C. and Bakker, P. A. H. M. 2012. Induced systemic resistance in Arabidopsis thaliana against Pseudomonas syringae pv. tomato by 2,4-diacetylphloroglucinol-producing Pseudomonas fluorescens. Phytopathology 102:403412.

Yoo, S.-J. and Sang, M. K. 2017. Induced systemic tolerance to muliple stresses including biotic and abiotic factors by rhizobaceria. Res. Plant Dis. 23:99-113 (in Korean). 